The Economic Journal of Nepal, Vol.41, No. 3 \& 4, July-December 2018 (Issue No. 150) @ Cedecon-TU

\title{
Industrial Development in Nepal: Problems and Prospects
}

\author{
Mukti Bahadur Khatri ${ }^{1}$
}

\begin{abstract}
Industry has historically played an important role in contributing to economic growth and employment of many countries around the world. It is imperative to give high priority to Nepalese labor, skill and raw material based domestic investments to promote national level industries for achieving high employment and economic growth. So, this study examines analytically the industrial development of Nepal for the period 1960 to 2018 based on secondary data. As an outcome of this sector is found to be a more potential sector and contributing a significant role in sustain and wide economic growth in Nepal even in reality it has less contribution as its potential capacity in the past.
\end{abstract}

Keywords: Industry, Industrial development, Economic growth, Employment, Prospects.

\section{Introduction}

Nepal is trying to achieve a growth path in the last decade but results are an average 4.3 percent (MoF, 2018) and flourish the growth of rent seeking in spite of high, wide and sustained economic growth. The economic development initiated in the last decade of an autocratic Rana Regime of more than 100 years, were particularly chaotic through establishment of industrial council. The initial years in the fifties, after freeing from a Rana Regime, the pace of economic development took place. The economic progress after 1990 has been encouraging through liberal economic policy but the real achievements have been overshadowed by the weakness of the politico-economic character of the ruling parties from time to time. Furthermore, the emergence of the Maoists in 1996 created a politicoeconomic crisis bringing to a close down the opportunities for socio-economic development. A new understanding among political parties including the Maoists in 2006 provided hope for structure a new Nepal. The 'Constitution of Nepal-2015', has transformed the political structure of the nation to a Federal Democratic republic with three levels of government namely federal government at the top, provincial government at the middle and local government at the bottom.

The contribution of the industrial sector to GDP was 5.5 percent in the last five fiscal years

1 Mr. Khatri is a Lecturer in Economics at Trichandra Multiple Campus, Ghantaghar, T.U., Nepal. Email: muktikc01@gmail.com. 
26 | The Economic Journal of Nepal (Issue No. 150)

whereas two decades ago, it was around 10 percent (MoF, 2018). It is, of course, as a share of the national economy manufacturing has reduced in size from about 10 percent in 19961997 to just over 6 percent in 2011-2012 (CBS, 2014). However, Nepal has continually tried to make a paradigm shift in the structure, thinking, way of economic behavior, responding to the contemporary changes or advancements in the world economic order over the years.

\section{Objectives of the Study}

The objectives of the study are to overview the trend of industrial development, industrial policies and acts along with explore the problems and prospects of industrial development in Nepal.

\section{Data and Methodology}

The study is fully based on secondary data and information collected from various books, booklets, journals, research reports, articles, working papers, conference proceedings, smarika, newspapers, and websites published by the concerned organization and institutions like Central Bureau of Statistics, Ministries of Finance, Industry, Commerce, and Supplies etc. The study used the yearly time series data from 1990/91 to 2017/18 with initially five years gap focusing on trends, policies and acts, problems and prospects of industrial development in Nepal. These materials have provided an insight of the overall situation of the economic and industrial position, problems and prospects of Nepal. The basic concept of industry and industrial development in Nepal is drawn through review of literature. The study used both qualitative and descriptive methods of data analysis.

\section{History of Industrial Development in Nepal}

In Nepal, industrial development started rather late due to the closed socio-political and economic status of the country during the Rana Regime. So, the history of industrial development dates back to 1936 beginning with the establishment of 'Industrial Council' in 1936. Thereafter, in 1940, 'Gharelu Illam Prachar Adda' (i.e. information dissemination about cottage level skill- based enterprises) was established. The early and gradually developed industries were cigarette and match factories. Raghupati Jute Mills established in 1946 is regarded as the first modern industry of Nepal (Khatri, 2018).

The development of industrial sector is a crucial to attain prosperity, generate employment, alleviate poverty, promote trade and stimulate growth of national income. But the industrial development of Nepal over past decades remains not much satisfactory. The manufacturing sector employed just 6.6 percent of the total workforce (NLFS, 2008). The contribution of manufacturing to total GDP was a minimal 6 percent in 2010. Most industries are located around various urban areas of the nation like Kathmandu Valley, Biratnagar, Simara, Birgunj, Hetauda, Pokhara, Butwal, Nepalgunj and other places of the Terai region (CBS, 2014). 
England was the first country in the world to bring about industrial revolution in the beginning of the $18^{\text {th }}$ century. The notable point here is that at that time there were no policies in Nepal related to industrial development. The process of planned industrialization started with the launching of the First Five-year Plan in 1956. Gradually, a number of small, medium and large-scale industries were established in the public along with private sectors.

The foundation for the industrial estates (IEs) was laid with the establishment of Balaju Industrial Estate (BIE) in 1963 with the technical and financial assistance from the United States of America (USA). The main reason behind establishing the industrial estates was to facilitate the development of industries and manufacturing enterprises in the country by providing basic infrastructures like land, roads, energy, water supply, sewerage, communication etc. at a specifically designated place.

Industrial Development Management Limited (IDML) was constituted by the Government of Nepal (GoN) in July 1988 in order to boost the balanced regional development by making optimum utilization of local capital, natural resources (agriculture and forest based etc.) and human resources for industrial promotion (IDML, 2018). There are 11 industrial estates and 10 are in operation except Dhankuta, six are being developed and five are proposed for consideration (MoF, 2018).

Table 1: Basic Information of Industrial Estates by 2018

\begin{tabular}{|c|c|c|c|c|c|c|c|c|c|}
\hline \multirow{2}{*}{ S. N. } & \multirow{2}{*}{ Industrial Estates } & \multirow{2}{*}{$\begin{array}{l}\text { Estd. } \\
\text { Year }\end{array}$} & \multirow{2}{*}{$\begin{array}{l}\text { Financial } \\
\text { Assistance }\end{array}$} & \multirow{2}{*}{ Location } & \multirow{2}{*}{ Employment } & \multirow{2}{*}{$\begin{array}{c}\text { Land Area } \\
\text { (in ha.) }\end{array}$} & \multicolumn{3}{|c|}{ No. of Industries } \\
\hline & & & & & & & Total & Running & Closed \\
\hline 1 & Balaju & 1960 & USA & Kathmandu & 4200 & 34.09 & 141 & 125 & 5 \\
\hline 2 & Patan & 1963 & India & Lalitpur & 2000 & 14.91 & 118 & 113 & 2 \\
\hline 3 & Hetauda & 1963 & USA & Makwanpur & 4100 & 158.73 & 134 & 102 & 4 \\
\hline 4 & Dharan & 1972 & India & Sunsari & 797 & 10 & 35 & 29 & 3 \\
\hline 5 & Nepalgunj & 1973 & India & Banke & 991 & 11.65 & 35 & 33 & 2 \\
\hline 6 & Pokhara & 1974 & Nepal & Kaski & 3000 & 25.5 & 89 & 81 & 3 \\
\hline 7 & Butwal & 1976 & Nepal & Rupandehi & 1859 & 22.09 & 72 & 65 & 3 \\
\hline 8 & Bhaktapur & 1979 & Germany & Bhaktapur & 800 & 3.63 & 37 & 36 & 1 \\
\hline 9 & Dhankuta & 1980 & Nepal & Dhankuta & NA & 3.26 & NA & NA & NA \\
\hline 10 & Birendranagar & 1981 & Netherlands & Surkhet & 300 & 4.58 & 28 & 22 & 2 \\
\hline \multirow[t]{2}{*}{11} & Gajendranarayan & 1986 & India & Saptari & 40 & 14.96 & 11 & 5 & 4 \\
\hline & Total & & & & 18087 & 303.40 & 700 & 611 & 29 \\
\hline
\end{tabular}

Source: IDML, 2018.

The table 1 shows that 10 industrial estates have been providing different facilities as a basic requirement of 700 industries. Among them 611 are operating their business and 29 are closed. These industries are providing 18,087 employments. Out of 8 industrial estates are established under the assistance of foreign countries whereas only two are established by the GoN. 
28 | The Economic Journal of Nepal (Issue No. 150)

The Special Economic Zone (SEZ) Act - 2017 has formulated for the establishment of export promotion of Nepal. So, the government of Nepal agreed to the concept of SEZ by attracting foreign and national investors to establish industrial and business activities. After this, the government has so far declared two SEZs which are one in Bhairahawa of Rupandehi District and another in Simara of Bara District. Similarly, in total the government has planned to create a minimum of seven SEZs throughout the country; making one SEZ in each of the seven provinces. The Ministry of Industry, Commerce and Supplies has completed feasibility study of establishing SEZ in Biratnagar of Province-1, Panchkhal of Bagmati Province, Gorkha of Gandaki Province, Jumla of Karnali Province and Dhangadhi of Sudur Paschim Province as well as eleven are proposed for consideration (MoF, 2018).

Table 2: Scale-wise Registration of Industries by 2017

\begin{tabular}{|c|c|c|c|c|c|c|}
\hline $\begin{array}{c}\text { Scales of } \\
\text { Industries }\end{array}$ & $\begin{array}{c}\text { No. of } \\
\text { Industries }\end{array}$ & Percent & $\begin{array}{c}\text { Total Capital } \\
\text { (Rs. in millions) }\end{array}$ & Percent & $\begin{array}{c}\text { No. of } \\
\text { Employment }\end{array}$ & Percent \\
\hline Large & 856 & 0.24 & $9,81,326.79$ & 65.93 & $1,26,974$ & 4.44 \\
\hline Medium & 1,482 & 0.42 & $1,23,922.52$ & 8.32 & $1,40,873$ & 4.93 \\
\hline Small & 4,186 & 1.17 & $64,159.81$ & 4.31 & $2,53,966$ & 8.88 \\
\hline Cottage & $3,48,870$ & 98.17 & $3,19,330$ & 21.44 & $23,37,373$ & 81.75 \\
\hline Total & $3,55,394$ & 100 & $14,88,739.12$ & 100 & $28,59,186$ & 100 \\
\hline
\end{tabular}

Source: Department of Industry, Ministry of Industry, Government of Nepal, 2017.

The table 2 shows that cottage industries cover almost 98.17 percent out of total industries in low investment i.e. 21.44 percent and provide mass employment 81.75 percent in comparison to others. Similarly, cottage, small and medium scale industries cover almost 99.76 percent out of total industries in low investment i.e. 34.07 percent and provide mass employment i.e. 95.56 percent in comparison to large scale industries. Therefore, to generate employment opportunities within a domestic economy, the government of Nepal should promote and develop small and cottage industries.

\section{Industrial Policies and Acts in Nepal}

Public policy is commonly used in daily activities for the betterment of the people and social welfare. Policy could be defined as a set of guidelines for action aimed at achieving goals and objectives thereby satisfying the needs of society in general. A public policy initially derives from the state institutions- both local, province and central level.

Industrial policy of Nepal can be divided into two time-periods like pre and post 1985. One side, before 1985 policies were guided by inward looking protectionist strategies. Domestic industries were treated as 'Infant Industries' and were protected from foreign competition by high tariff and quota restrictions. The government was directly involved in the economy and provided essential products and services. Another side, liberalization initiated in 1985 and accelerated after the 1990s, sought to modernize the economy and accelerate structural 
changes by creating an environment appropriate for private sector participation. The government began to withdraw from the economy and policies were implemented to promote private and foreign investment. A new 'Liberal Industrial Policy' was formulated and that seeks to create an open and competitive economy by curtailing government interference in price fixing of industrial goods (SAWTEE, 2007).

Nepal has followed an international trend of devising subject- specific policies in order to drive the nation toward a sustainable development path. Hence, the government has devised, revised and reformed its industrial policies from time to time and formulated necessary acts to create an enabling industrial atmosphere. The major thrust behind devising various policies has been on openness with emphasis on market driven strategies and encouraging the private sector to play a dominant role in economic development.

In recent years, the government of Nepal has updated, refined and revised various policies and acts on the basis of lessons learned and / or problems encountered while trying for industrial growth, exports promotion, imports substitution, employment generation and overall economic transformation and development. These policy frameworks and enactments have helped build confidence of the private sectors for their greater participation in economic activities through industrialization. The major characteristics of the various policies, acts and strategies are shortened as follows:

Table 3: Features of various Industrial Policies of Nepal

\begin{tabular}{|c|c|c|c|}
\hline S.N. & Policies & \multicolumn{1}{c|}{ Main Features } \\
\hline 1 & $\begin{array}{c}\text { Industrial } \\
\text { Policy - 1960 }\end{array}$ & $>\begin{array}{l}\text { Tax holiday and more facilities to the industries established in } \\
\text { remote areas. }\end{array}$ \\
\hline 2 & $\begin{array}{c}\text { Industrial } \\
\text { Policy - 1974 }\end{array}$ & $>\begin{array}{l}\text { Special consideration on customs duty. } \\
\text { small industries. }\end{array}$ \\
& $>$ Supported by high tariff barrier and quota restrictions. \\
& $>$ Developed the government enterprises.
\end{tabular}


30 | The Economic Journal of Nepal (Issue No. 150)

\begin{tabular}{|c|c|c|}
\hline 6 & $\begin{array}{c}\text { Industrial } \\
\text { Policy - } 2010\end{array}$ & $\begin{array}{l}\text { Development of quality infrastructures and environment } \\
\text { friendly new technology. } \\
>\text { Focused on joint efforts of public, private and cooperative } \\
\text { sectors. } \\
>\text { Prioritized export potential products by using local resources. } \\
>\text { Enhancing enforcement capacity of the government. } \\
>\text { Promotion of good governance. } \\
>\text { Coherence between industrial, trade and transit policy. } \\
>\text { Development of agriculture and forest sector. } \\
>\text { Increase employment generation and boost per capita income. } \\
>\text { Promote Special Economic Zones (SEZs). } \\
>\text { 'One-window' policy for all industrial activities. } \\
>\text { No work, no pay. }\end{array}$ \\
\hline
\end{tabular}

Source: Various policies issued by MolCS.

Industrial policy environment plays a significant role in accelerating economic growth and achieving goals of development. In the globalized era, as a Least Developed Country (LDC), Nepal faces numerous challenges in ensuring an enabling trade and industrial environment. Ever since 1960, various policies have been implemented to promote the industrial sector. But the country is far behind the desired progress. Despite the implementation of economic reform measures, mainly in the 1990s, exports performance has continued to remain weak.

The government has been concentrating its efforts on creating a conducive environment for the private sector to increase investment in the country. Specifically, various governments formed after 1990 have tried to create a conducive environment for economic development by formulating new industrial policies and replacing older ones in pace with the changing environment within the country as well as the entire world. Accordingly, the government promulgated various policies to boost an enabling environment for the growth of the manufacturing sector, attract foreign as well as domestic investments, generate income and employment and thereby raise the quality of life of the Nepali society. The policy provisions post - 1990 were the major foundations playing crucial roles in attracting investment for industrial development.

\section{No Work No Pay Principle}

The Industrial Policy-2010 promises flexible labor policy regarding the 'No work, no pay' principle. It shall be followed as provided by the labour law with the objective of creating cordial relationship between employers and employees and to create additional employment opportunities. Industrial sector of Nepal experienced a series of misunderstandings between the industry and its workers, which not only affected industrial outputs but also slowed down the entire industrial growth of the country. There were instances of many industries shutting down their operation due to industry-worker conflict in the past. That is why industrial productivity in Nepal is very low. Therefore, to build a friendly environment the 'No-work- 
no-pay' policy should be implemented as a social security. Such social security will increase factory-worker good relationships and foster the growth of the industrial sector as well as the entire economy. It is only after assuring cordial industry-labour relationship in the country attracts domestic and foreign investment at a tangible amount. Thus, one side, while factories should understand that better output can be achieved only by encouraging its workers to give their best. On the other hand workers should note that they will be able to enjoy better facilities only if the factory performs well. Accordingly both factory owners and workers have acknowledged this fact for the betterment of industrial progress. In this way, the industrial output of the country can grow in the future.

\section{Present Status of Industrial Development}

The study presents and analyses the performance of the industrial sector of Nepal and its social, environmental as well as regional impacts. It describes that the manufacturing sector could not keep pace with the development of the rest of the economy. Factors that created barriers to further development can be found in the sphere of governance, infrastructure, labor, skills and social relations.

Table 4: Industrial Production, Growth and Contribution to RGDP (in millions NPR)

\begin{tabular}{|c|c|c|c|c|}
\hline $\begin{array}{c}\text { Fiscal } \\
\text { Years }\end{array}$ & $\begin{array}{c}\text { Industrial } \\
\text { Production }\end{array}$ & $\begin{array}{c}\text { Growth of Industrial } \\
\text { Sector (in \%) }\end{array}$ & $\begin{array}{c}\text { Contribution of Industrial } \\
\text { Sector to RGDP (in \%) }\end{array}$ & $\begin{array}{c}\text { Total Real } \\
\text { GDP }\end{array}$ \\
\hline $1990 / 91$ & 12179 & 15.02 & 4.61 & 263955 \\
\hline $1995 / 96$ & 21322 & 8.29 & 6.33 & 336681 \\
\hline $2000 / 01$ & 38409 & 30.63 & 9.29 & 413428 \\
\hline $2005 / 06$ & 38898 & 2 & 8.09 & 480435 \\
\hline $2010 / 11$ & 41923 & 4.1 & 7.14 & 587534 \\
\hline $2015 / 16$ & 44223 & -8 & 6.36 & 695688 \\
\hline $2016 / 17$ & 48510 & 9.7 & 6.47 & 749550 \\
\hline $2017 / 18$ & 52957 & 9.17 & 6.65 & 796784 \\
\hline
\end{tabular}

Source: Author's construction from different Economic Surveys, MoF, Nepal.

The table 4 shows that industrial production is continuously increasing except FY 2015/16 where industrial growth rate became negative i.e. -8 percent. However, growth of the industrial sector itself became more than 30 percent in 2000/01. But the GoN is unable to continue this progress. Similarly, the contribution of the industrial sector in real GDP is almost small i.e. less than 10 percent. Accordingly, real GDP is continuously increasing. Therefore, the industrial sector should be expanded significantly in the years ahead and turned out to be one of the major sectors for the massive driven sector of the economy of Nepal through its growth and development. 
32 | The Economic Journal of Nepal (Issue No. 150)

Table 5: Registration of Different Nature of Industries up to 2018

\begin{tabular}{|l|c|c|c|c|c|}
\hline \multicolumn{1}{|c|}{ Categories } & $\begin{array}{c}\text { No. of } \\
\text { Industries }\end{array}$ & $\begin{array}{c}\text { Total Capital } \\
\text { (Rs. in millions) }\end{array}$ & $\begin{array}{c}\text { Fixed } \\
\text { Capital }\end{array}$ & $\begin{array}{c}\text { Working } \\
\text { Capital }\end{array}$ & $\begin{array}{c}\text { Employment } \\
\text { Generation }\end{array}$ \\
\hline $\begin{array}{l}\text { Agriculture and } \\
\text { forest based }\end{array}$ & 442 & 23267.22 & 20117.54 & 3267.69 & 34898 \\
\hline Construction & 55 & 48898.03 & 47473.36 & 1424.68 & 3648 \\
\hline Energy based & 329 & 929637.6 & 910526.67 & 19110.92 & 31291 \\
\hline $\begin{array}{l}\text { Information } \\
\text { Technology }\end{array}$ & 38 & 1651.5 & 1377.45 & 274.05 & 1852 \\
\hline Manufacturing & 2897 & 396695.2 & 307014.32 & 90151.38 & 312591 \\
\hline Mineral & 68 & 6870.81 & 5756.39 & 1116.52 & 7119 \\
\hline Service & 2085 & 144828.95 & 95992.45 & 48882.5 & 119992 \\
\hline Tourism & 1615 & 129070.55 & 117056.96 & 12005.39 & 64105 \\
\hline Total & $\mathbf{7 5 2 9}$ & $\mathbf{1 6 8 0 9 1 9 . 8 6}$ & $\mathbf{1 5 0 5 3 1 5 . 1 4}$ & $\mathbf{1 7 6 2 3 3 . 1 3}$ & $\mathbf{5 7 5 4 9 6}$ \\
\hline
\end{tabular}

Source: Based on Industrial Statistics, 2017/18.

The table 5 shows that the share of manufacturing industries had occupied at the top and followed by service and tourism industries up to 2017/18. Similarly, as an investment commitment, the total investment is on energy-based industries at the top and followed by manufacturing, service and tourism industries. But more employment is generated by manufacturing industries.

Table 6: Registered of Scale-wise Industries up to 2018

\begin{tabular}{|l|c|c|c|c|c|c|}
\hline $\begin{array}{c}\text { Scales of } \\
\text { Industries }\end{array}$ & $\begin{array}{c}\text { No. of } \\
\text { Industries }\end{array}$ & Percent & $\begin{array}{c}\text { Total Capital } \\
\text { (Rs. in millions) }\end{array}$ & Percent & $\begin{array}{c}\text { No. of } \\
\text { Employment }\end{array}$ & Percent \\
\hline Large & 1030 & 13.68 & 1452564.3 & 86.42 & 149263 & 25.94 \\
\hline Medium & 1,640 & 21.78 & 149426.37 & 8.89 & 152504 & 26.50 \\
\hline Small & 4,859 & 64.54 & $78,929.22$ & 4.69 & 273729 & 47.56 \\
\hline Total & 7,529 & 100 & 1680919.9 & 100 & 575496 & 100 \\
\hline
\end{tabular}

Source: Department of Industry, Ministry of Industry, GoN, 2018.

The table 6 shows that small scale industries covers almost 65 percent out of total industries in low investment i.e. around 5 percent and provides more employment about 48 percent in comparison to others. Similarly, small and medium scale industries cover almost 87 percent out of total industries in low investment i.e. 14 percent and provide mass employment of 75 percent in comparison to large scale industries. Therefore, to generate employment opportunities within a domestic economy, the government of Nepal should promote and develop SMEs. 
Table 7: Foreign Investment on Nepalese Industries for the Last Five Years (Rs. in 10 millions)

\begin{tabular}{|l|c|c|c|c|c|}
\hline $\begin{array}{c}\text { Fiscal } \\
\text { Years }\end{array}$ & $\begin{array}{c}\text { No. of } \\
\text { Industries }\end{array}$ & $\begin{array}{c}\text { Foreign } \\
\text { Investment }\end{array}$ & $\begin{array}{c}\text { Fixed } \\
\text { Capital }\end{array}$ & $\begin{array}{c}\text { Total } \\
\text { Capital }\end{array}$ & $\begin{array}{c}\text { Employment } \\
\text { Generation }\end{array}$ \\
\hline $\mathbf{2 0 1 3 / 1 4}$ & 307 & 2013.2 & 3504.9 & 4073.7 & 11790 \\
\hline $\mathbf{2 0 1 4 / 1 5}$ & 370 & 6745.5 & 7743.7 & 8137.1 & 13167 \\
\hline $\mathbf{2 0 1 5 / 1 6}$ & 348 & 1525.4 & 1416.5 & 2054.4 & 11663 \\
\hline $\mathbf{2 0 1 6 / 1 7}$ & 398 & 1511.3 & 1233.3 & 1700.3 & 11734 \\
\hline $\mathbf{2 0 1 7 / 1 \mathbf { B } ^ { * }}$ & 194 & 3491.1 & 3548.7 & 3804.1 & 7541 \\
\hline Total & $\mathbf{1 6 1 7}$ & $\mathbf{1 5 2 8 6 . 5}$ & $\mathbf{1 7 4 4 7 . 1}$ & $\mathbf{1 9 7 6 9 . 6}$ & $\mathbf{5 5 8 9 5}$ \\
\hline
\end{tabular}

Note: An asterisk * denotes the first eight months of the FY 2017/18.

Source: Economic Survey, 2018.

The table 7 shows that the number of industries and foreign investment has been continuously increasing. Accordingly, even in the first eight months of the FY 2017/18, the commitment of foreign investment has been made two fold than the previous FY 2016/17. This means formation of stable government attracts foreign investment significantly.

Table 8: Country-wise Investment on Nepalese Industries (Rs. in 10 millions)

\begin{tabular}{|l|c|c|c|c|c|}
\hline \multicolumn{1}{|c|}{ Countries } & $\begin{array}{c}\text { No. of } \\
\text { Industries }\end{array}$ & $\begin{array}{c}\text { Total } \\
\text { Investment }\end{array}$ & $\begin{array}{c}\text { Foreign } \\
\text { Investment }\end{array}$ & $\begin{array}{c}\text { Share } \\
\text { in Total } \\
\text { Investment }\end{array}$ & $\begin{array}{c}\text { Employment } \\
\text { Generation }\end{array}$ \\
\hline India & 713 & 13652.8 & 8680.3 & 35 & 68655 \\
\hline China & 1226 & 9191.3 & 6346.7 & 25.6 & 56505 \\
\hline China Hong Kong & 36 & 3707.2 & 2728.2 & 11 & 4782 \\
\hline South Korea & 324 & 1624.5 & 1149 & 4.6 & 11070 \\
\hline USA & 375 & 2083.7 & 838 & 3.4 & 17654 \\
\hline British Virgin Island & 16 & 1630.3 & 806.4 & 3.3 & 2180 \\
\hline UK & 169 & 897.2 & 538.6 & 2.2 & 10702 \\
\hline Mauritius & 10 & 391.8 & 335.5 & 1.4 & 974 \\
\hline Singapore & 44 & 820.7 & 296.2 & 1.2 & 3207 \\
\hline UAE & 17 & 540.6 & 290.4 & 1.1 & 1827 \\
\hline Other 82 Countries & 1343 & 6853.7 & 2776.5 & 11.2 & 59578 \\
\hline Total 92 Countries & $\mathbf{4 2 7 3}$ & $\mathbf{4 1 3 9 3 . 8}$ & $\mathbf{2 4 7 8 5 . 8}$ & 100 & $\mathbf{2 3 7 1 3 4}$ \\
\hline
\end{tabular}

Note: An asterisk * denotes first eight months of the FY 2017/18.

Source: Economic Survey, 2018. 
34 | The Economic Journal of Nepal (Issue No. 150)

The table 8 shows that on the basis of project cost of the approved industries for foreign investors, the shares of Indian investors have occupied 35 percent of total foreign investment. Similarly, China occupied the second position in the investment which is 25.6 percent and China Hong Kong is in the third place with 11 percent investment in share. Similarly, the share that has been invested by investors of India, China and China Hong Kong to total foreign investment is 39 percent, 16 percent and 13 percent correspondingly. In the latter period, the share of Chinese investors has been increasing to total foreign investment. So, foreign investment by the first eight months of the current FY 2017/18, the shares of investors of China, India and the USA has been 28.7 percent, 16.7 and 8.8 percent respectively (MoF, 2018).

\section{Distribution of Industries by Provinces}

The distribution of industries, capital and employment generation in 7 provinces under the federal democratic republic of Nepal can be shown as follows.

Table 9: Province-wise Registration of Industries by 2018

\begin{tabular}{|l|c|c|c|c|c|}
\hline $\begin{array}{c}\text { Names of } \\
\text { Provinces }\end{array}$ & $\begin{array}{c}\text { No. of } \\
\text { Industries }\end{array}$ & Percent & $\begin{array}{c}\text { Total Capital } \\
\text { (Rs. in 10 millions) }\end{array}$ & $\begin{array}{c}\text { Employment } \\
\text { Generation }\end{array}$ & Percent \\
\hline Province-1 & 673 & 9.18 & 34263.7 & 73610 & 12.98 \\
\hline Province-2 & 491 & 6.69 & 8374.9 & 50246 & 8.86 \\
\hline Bagmati & 4961 & 67.64 & 58602.4 & 345947 & 61.01 \\
\hline Gandaki & 556 & 7.58 & 25930.2 & 32441 & 5.72 \\
\hline Province-5 & 508 & 6.93 & 15521.3 & 52965 & 9.34 \\
\hline Karnali & 38 & 0.52 & 10981.7 & 2562 & 0.46 \\
\hline $\begin{array}{l}\text { S u d u r } \\
\text { Paschim }\end{array}$ & 107 & 1.46 & 2643.3 & 9263 & 1.63 \\
\hline Total & 7334 & 100 & $\mathbf{1 5 6 3 1 7 . 5}$ & $\mathbf{5 6 7 0 3 4}$ & 100 \\
\hline
\end{tabular}

Source: Economic Survey, 2018.

The table 9 shows that among registered industries from the beginning to $2017 / 18$, about 4961 industries have been registered in -+Bagmati Province that covered one third of the total industries of Nepal, whereas the lowest figure of 38 industries in Karnali Province. Similarly, on the basis of investment, Bagmati Province is at the top i.e. Rs 58602.4 Crore and Sudurpaschim at the bottom i.e. Rs. 2643.3 Crore. 
Figure 1: Province wise Distribution of Industries by 2018

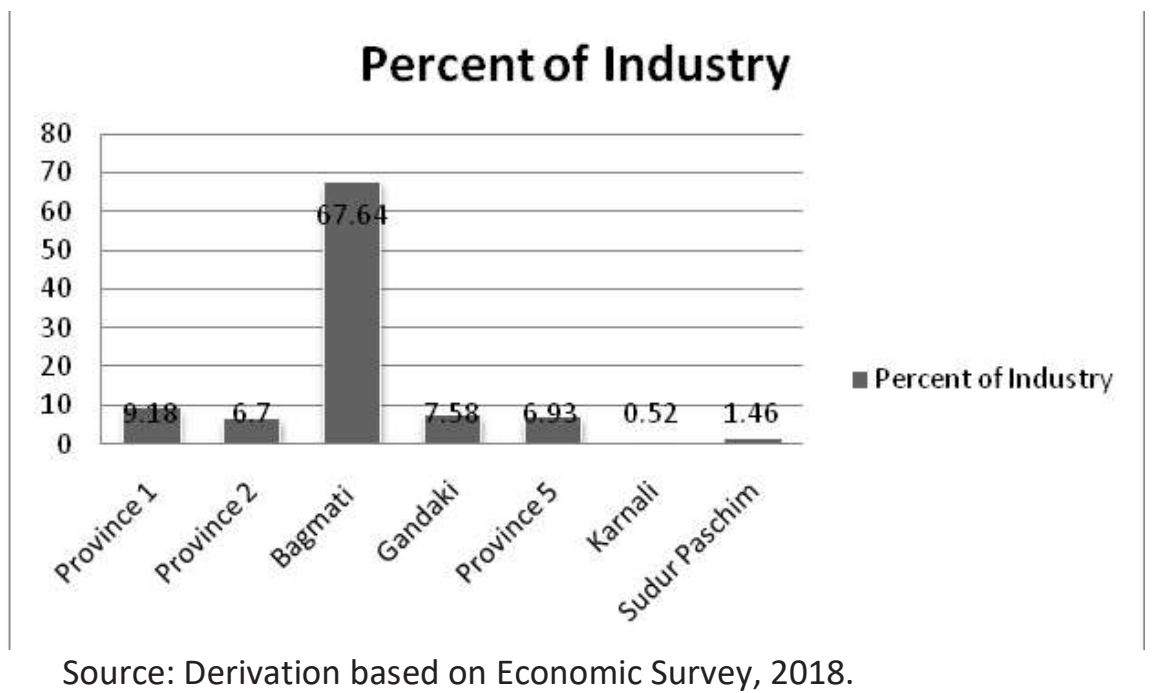

Figure 1 shows that about 68 percent industries are centralized in Bagmati Province while Sudur Pashim and Karnali Provinces secured only 1 and less than 1 percent of existing industries of Nepal.

Figure 2: Province-wise Employment Generation on Industries by 2018

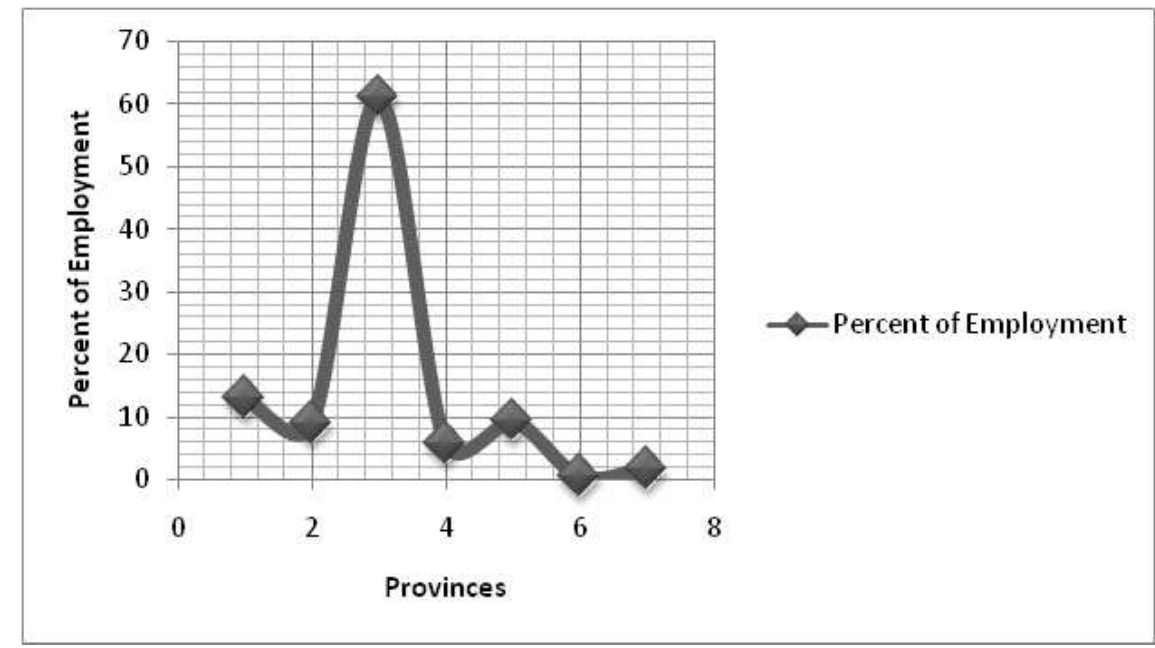

Source: Derivation based on Economic Survey, 2018.

Figure 2 shows that about 61 percent of people were employed in Bagmati Province while only 2 and less than 1 percent was employed in Sudur Paschim and Karnali Provinces of Nepal respectively. 
36 | The Economic Journal of Nepal (Issue No. 150)

\section{Distribution of Cottage and Small Industries By Provinces}

The governments of all provinces have been trying hard to raise the development of cottage and small scale industries. For the purpose it has been devising various policies and making or revising acts and changes in rules from the beginning in order to attract investments in the manufacturing sector as well as stressing on the expansion of the availability of resources.

Table 10: Distribution of Cottage and Small Industries by Provinces

\begin{tabular}{|l|c|c|c|c|c|c|}
\hline Provinces / FY & $\mathbf{2 0 1 3 / 1 4}$ & $\mathbf{2 0 1 4 / 1 5}$ & $\mathbf{2 0 1 5 / 1 6}$ & $\mathbf{2 0 1 6 / 1 7}$ & $\mathbf{2 0 1 7 / 1 \mathbf { F } ^ { * }}$ & Total \\
\hline Province - 1 & 2455 & 4095 & 3387 & 4333 & 1904 & 16174 \\
\hline Province - 2 & 2583 & 2819 & 2318 & 4820 & 3187 & 15727 \\
\hline Bagmati & 7530 & 8419 & 8275 & 10057 & 5532 & 39813 \\
\hline Gandaki & 2234 & 3039 & 2598 & 3180 & 2371 & 13422 \\
\hline Province - 5 & 5330 & 4809 & 4494 & 5637 & 3774 & 24044 \\
\hline Karnali & 742 & 1225 & 1202 & 1579 & 506 & 5254 \\
\hline Sudur Paschim & 1280 & 1864 & 2043 & 2433 & 1288 & 8908 \\
\hline \multicolumn{1}{r|}{ Total } & $\mathbf{2 2 1 5 4}$ & $\mathbf{2 6 2 7 0}$ & $\mathbf{2 4 3 1 7}$ & $\mathbf{3 2 0 3 9}$ & $\mathbf{1 8 5 6 2}$ & 123342 \\
\hline
\end{tabular}

Note: An asterisk * denotes the first eight months of the FY 2017/18.

Source: Economic Survey, 2018.

The table 10 shows that in the FY 2016/17, 32,039 cottage and small industries have been registered in the office under the Department of Cottage and Small Industries and Cottage and Small Industries Development Committee. Similarly, in the last 5 years, the highest number of domestic and small enterprises was registered in Bagmati Province, whereas the lowest number of enterprises was registered in Karnali Province.

\section{Problems to Industrial Development in Nepal}

Despite various plan and policy provisions, positive laws and rules, the investors have been facing many barriers to enabling the environment in the industrial sector. Road closures, strikes by laborers and Nepal Bandh (total closure of the economic activities) are frequently declared by either political parties or any groups. It is quite amazing in Nepal that even the "most essential services" are also not tolerated by the call of the law or the directives of the government. Even hospitals, telecommunication, sanitation and electricity workers have a tendency to go on strikes and force the country to fulfill their unnecessary as well as unethical demands. The major problems are:

Inadequate Physical and Social Infrastructures:- Physical infrastructures such as road, energy, communication, irrigation and social infrastructures such as education, health and sanitation are insufficient. That is why private sectors are also centralized in urban areas only. 
Therefore, the industrial sector of Nepal does not flourish even though its process started 60 years ago and is suffering from basic requirements.

Lack of Corporate Culture and Institutions:- Lack of corporate culture and intuitional development energetic people of Nepal are unable to develop managerial and entrepreneurial skills for maximum utilization of available resources. Business community is not taking risk by establishing new industries. However, they are actively participating in trading.

Lack of Political Stability and Will-Power:- Nepal has been unable to mobilize resources even if it has sufficient water resources, human resources, natural beauties, cultural heritages and bio-diversities because of long standing instability and lack of strong willpower of political leaders.

Vicious Circle of Poverty:- About 21 percent people are living below absolute poverty line (MoF, 2018). So, energetic youths are facing problems of capital deficiency. On the basis of the principle of vicious circle in UDCs' level of income remains low, this leads to low level of saving and investment. Consequently, low investment leads to low productivity which again leads to low income. In economics, the cycle of poverty is the "Set of factors or events by which poverty, once started, is likely to continue unless there is outside intervention". The poverty cycle can be called the "Development trap" when it is applied to countries.

Socio Cultural Constraints:- Socio-cultural values are one of many interacting factors that can impact economic as well as industrial development and influence on how we approach the process of economic development due to a set of values, beliefs, traditions and habits.

Market Imperfection:- Imperfect market becomes a barrier to achieve economic efficiency and fair business activities. On the contrary, under perfect competition, a firm or industry can operate at the point where there is no surplus of capacity that means resources are fully utilized.

Low Competitive Power and Human Resource Development:- In this age of global competition, it is not just enough for the Nepalese firms to be competitive at the domestic level. For that industrial sector should have to improve economies of scale through technological advancement, marketing strengths, efficient production and distribution systems as well as affordable labor. Building up skill and competitive human resources is the key for catching opportunities for market opening and widening. East Asian countries have good examples of success stories. So, industrial sectors have low competitive power due to less development of human resource than required.

Difficult Geographical Location:- Nepal is surrounded by India on three sides and China on one side. So, it is a land-locked country whose transit facilities are determined by the willingness of India. Nepal has a bitter past experience in case of export and import. Now, the government of Nepal can eliminate this difficulty through diplomatic relationships with these countries as most favored nations. On the other hand, difficult topography is a challenge to achieve balanced and inclusive development by addressing geographically between villages and towns, mountains, hills and terai as well as on the basis of castes, groups, genders and provinces. 
i) Good Governance:- It refers to providing a legal and regulatory framework and enlightened fiscal and strategic direction for promotion of economic growth and development. The attitudes and perceptions of management have been frequently cited as important determinants of economic performance. Many problems are caused by lack of clarity in laws and regulations and unpredictability and inconsistency in their implementation. Sometimes, policies and regulations are made without the suggestions and knowledge of the private sector. Firms also complained about excessive government red tape, public services delays and corruption. Implementation of the import regime (problems with customs and duty drawbacks), the tax regime (inappropriate revenue targets and poor tax administration), and the labor law (inflexible economizing provisions) affect exporters mostly.

j) Lack of Research and Development:- Research is required for the exploration and extension of the economy in domestic as well as third countries. But in case of Nepal, there is no adequate institutional infrastructure for this purpose. In spite of these constraints, the economy of Nepal has shown potential to be competitive in several areas. This is supported by analysis of abundant resource, domestic resource costs, price differentials and revealed comparative advantage. However, given the increasing volatility and competition of global markets, Nepal must make considerable efforts to improve the industrial sector as its potential.

Problems facing Nepal is her inability to attract foreign private capital, imports and exports with third countries transit through only the port of Kolkata, investment opportunities in large scale industries are limited by extremely low purchasing power of the population and country's remoteness and poor endowment of mineral resources, knowledge of finance of marketing (whether for the country-wide distribution of goods or for exports) and even of simple management procedures and accounting practices is woefully inadequate, entrepreneurship and management capacity has been very inadequate, failure to exploit known investment opportunities, social preferences for maintaining status quo than increasing production, investment in land and eye-catching consumption rather than investment in industries, lack of efficiency, initiative and organization in industrial operations are some of the more important impediments. It is necessary to introduce appropriate educational programs with emphasis on training to entrepreneurs for industrial progress. The size and behavior of markets are also major limiting factors in the industrialization of the economy (Nepal, 2004).

Therefore, the role of government required foremost changes in above mentioned problems through suitable plan and policy interventions for improving long-term economic performance to provide more than enough scope to the domestic economy to integrate with the global economy through industrial development.

\section{Prospects of Industrial Development in Nepal}

Economic growth is the steady process by which the productive capacity of the economy is increased over time as the potential capacity of existing resources whereas development 
is the process of improving the quality of life of the people. Economic growth is measurable and economic development can be used to describe the underlying determinants of economic growth. However, to achieve rapid economic growth through industrial development, there should be development of export oriented manufacturing industries. Promotion of export based industries and diversification of export market are the major factors which significantly contribute to expanding economic activities and uplift the living standard of the people. Therefore, there is opportunity in the following areas for promotion and development of the industrial sector as well as to improve prosperity of the country. The major prospects of industrial development in Nepal are:

Hydro-electricity:- There is a significant prospect of hydroelectricity due to high water current and 6000 rivers whose length are about $45000 \mathrm{~km}$ as well as estimated that about $44000 \mathrm{MW}$ of economically feasible electricity can be generated from the available water resources. So, it has potential to promote industrial as well as agriculture production.

Tourism:- Nepal is full of natural beauty, great Himalayas, adventure places, unique cultural heritages, wide range of biodiversity and historical religious places. So, there are ample opportunities in the tourism industry.

Forest / Herbs:- The total area covered by forests in Nepal remains about 40.4 percent and thousands community forest user groups. In the context of sustainable conservation of biodiversity, about 23.4 percent of the total land is covered by conservation areas (MoF, 2018). In Himalayan and Hilly regions, there are different species of herbs such as Peepla, Timmur, Yarchagumba, Neem, Harro, Barro, Panchaaule, large cardamom, ginger, turmeric etc. are available.

Agro-processing:- Majority of the people are dependent for their income and employment in agriculture and contribute 27.59 percent in GDP (MoF, 2018). So, possibility of agrobased industries such as sugar, tea, mango juice, apple juice, bel juice, tobacco, honey, milk, fish, meat and floriculture etc.

Information Technology:- Information technology has emerged as a strong means for developing business sectors such as tele-medicine, tele-education, e-commerce, e-trade, egovernance and so forth.

Human Resource Development:- Nepal has also potentiality to improve and capitalize her human resources through applied education and different vocational training which would be appropriate to mobilize her available resources as its potential capacity like in East Asia. Above mentioned prospects are positive indications of bringing the pace of the industrial development of country and catch the track of prosperity.

\section{Conclusion}

Industrialization and industrial development are recognized as the principal of sustainable economic growth to provide stability and development, but its development trend is slow and challenging up to now as well as its contribution in GDP is less than 10 percent. In Nepal, 
40 | The Economic Journal of Nepal (Issue No. 150)

plans and policies reform efforts of over 60 years for the development of the industrial sector, but unable to improve economic performance through this sector. Similarly, the industrial infrastructure, entrepreneurial skills, technological capability, political will power and good governance constitute the key problems of industrial development. As a result, the country is facing an ever rising negative balance of trade as well as balance of payments situation. However, Nepal has a potentiality of hydro-power, tourism, herbal products, agro-processing, and human resource development. Accordingly, with the hope of more stable governments at federal, provincial and local level, a positive and enabling environment is required for the development of the industrial sector.

\section{References}

CBS (Central Bureau of Statistics) (2008). Nepal Labour Force Survey. Kathmandu: CBS.

CBS (Central Bureau of Statistics) (2011). Population Census - 2011. Kathmandu: CBS.

CBS (Central Bureau of Statistics) (2014). Development of Manufacturing Industries in Nepal: Current State and Future Challenges. Kathmandu. CBS, Nepal.

IDML (Industrial Districts Management Ltd.) (2018). Smarika. Kathmandu: IDML.

Khatri, M. B. (2018). Contribution of small and medium scale enterprises to generate

employment in Nepal. A mini-research report submitted to the Centre for Research, Rector's Office, Tribhuvan University, Kathmandu, Nepal.

MoICS (Ministry of Industry, Commerce and Supplies) (1992). Nepal Industrial Policy, 1992. Kathmandu: MoICS.

MoICS (Ministry of Industry, Commerce and Supplies) (2010). Nepal Industrial Policy, 2010. Kathmandu: MoICS.

MoICS (Ministry of Industry, Commerce and Supplies) (2018). Industrial Statistics, 2017/18. Kathmandu: MoICS.

MoF (Ministry of Finance) (2018). Economic Survey - 2017/18, Kathmandu: MoF.

Nepal, C. (2004). Industrial development in Nepal challenges and opportunities. In M. K. Dahal

Dahal, M.K. (2004). (Ed.). Nepalese economy towards building a strong economic nation state. (pp.527-546). Kathmandu: Central Department of Economics, TU: New Heera Books Enterprises.

NPC (National Planning Commission) (2090 to 2018). Plan Documents. Various Issues, Kathmandu, Nepal, Government, Nepal.

SAWTEE (South Asia Watch on Trade, Economics and Environment) (2007). A Review of Trade and Industrial Policy in Nepal. Research Brief: Kathmandu: SAWTEE.

World Bank (2018). World Bank Database. Retrieved from www.worldbank.org. www.lawcommission.gov.np 